\title{
Information seeking behaviour of undergraduate students in the humanities in three universities in Nigeria
}

\author{
Emmanuel E. Baro', George O. Onyenania ${ }^{2}$ and Oni Osaheni ${ }^{3}$ \\ Delta State University, Abraka, Delta State \\ karaperekumor@yahoo.com; onyenaniageorge@yahoo.com; chiefonism@yahoo.com
}

Received: 10 June 2010
Accepted 20 October 2010

\begin{abstract}
The purpose of this study is to establish the information needs, sources, and the information searching strategies of undergraduate students. The study adopted a descriptive survey method. The study covers 100-400 level undergraduate students in history in the humanities in three universities in the South-South geo-political zone of Nigeria. A sample size of 259 was used for the study. Random sampling technique was used in selecting the sampled respondents. The study opted the use of questionnaires, interviews and observation methods. It emerged that the undergraduate students use sources such as textbooks, journals, Internet, and rely heavily on human resources for information. The study also revealed that undergraduate students use search strategies such as starting, chaining, browsing, differentiating, monitoring and extracting. There is a significant difference between male and female students in the sources they use in obtaining information in the humanities and in their search strategies. Findings will enable library administrators and university management to see the need to integrate information literacy courses into the school curriculum. Also to enable librarians to intensify their efforts to educate students about the information environment rather than simply providing the knowledge of how to use specific tools.
\end{abstract}

Keywords: Universities; libraries; information seeking; search strategies, Nigeria

\section{Introduction}

Information seeking behaviour can be described as an individual's manner of gathering and sourcing information for personal use, knowledge updating and development. According to Kakai, Ikoja-Odongo and Kigongo-Bukenya (2004), information seeking behaviour is the way people go about searching for information. They also observed that students' information seeking behaviour involves purposeful information seeking as a result of the need to complete course assignments, prepare for class discussions, seminars, workshops, and write final-year research papers.

Taylor (2000) noted that the information sources (e.g. the library) that a user actually needs may not eventually tally with what is practically available, due to constraints either in the stock or the user's own inability. Kakai, Ikoja-Odongo and Kigongo-Bukenya (2004) in their study observed that most students concentrate on using particular materials recommended by either their lecturers or colleagues who have used them before, rather than searching to find the most appropriate document to use.

Recently, comparisons have emerged with other academic disciplines. According to Whitmire (2002) undergraduates in the humanities demonstrate a significantly higher use of library facilities than others. They more often use catalogues, turn to librarians for assistance, browse library collections, use reserve collections and journal indexes, etc. WatsonBoone (2004) identified the importance of the professional network of neighboring and distant colleagues in the information seeking behaviour of undergraduate students in the humanities.

Wilberley and Jones (2000) asserted that, though undergraduate students in the humanities do turn more frequently to librarians, they do so with some reluctance. Tibbo (2002) in her investigation of the information seeking behaviour of historians states that "we have no idea if they succeeded in finding these materials based on web searches" (p.5). Mann (2003) posited that most researchers, even with computers, find only a fraction of the sources available to them. He explained that undergraduates tend to work within one or another mental framework that limits their basic perception of the universe of knowledge available to them. Students according to him use a subject-disciplinary method that leads them to a specific list of sources on a particular subject. He points out that while this method allows students and researchers to find more specific sources, it is limiting in that they may not realize that work of interest to their own subject appears within the literature of many other disciplines. He also observed that users want 'good enough' sources, not necessarily the best sources available. The evaluation of 'good enough' is based on a number of factors, the most important being

I. Emmanuel E. Baro works as a Librarian II at the Niger Delta University Library, Amassoma, Bayelsa State, Nigeria.

2. George O. Onyenania has just completed his Masters Degree in the Department of Library and Information Science, Delta State University, Abraka, Delta State, Nigeria.

3. Oni Osaheni a Librarian in a Documentation Center, Benin City, Edo State, Nigeria. 
ease of access and availability of full-text sources. The sources chosen follow the principle of Least Effort; they tend to choose perceived ease of access over quality of content in selecting an information source or channel.

Undergraduate students in the Niger Delta University, Delta State University and University of Port-Harcourt are expected to maximally utilize the university libraries as their major source of information. However, noting from the studies conducted on library use, it was established that students do not use most of the library's information resources. Zondi (2002) in her study established that a majority of students show a very low level of competence in the use of a library and display poor information seeking patterns. It could be assumed that students could be experiencing technical problems in accessing information resources; being card catalogues, the library catalogues do not provide adequate access to the libraries' collections; or students are information illiterate and lack the required library literacy skills. Baro and Fynman (2009) in their study pointed out factors such as: information illiteracy among library users; absence of computer systems with Internet connectivity in the university libraries; poorly conducted user education programmes; reliance on manual information retrieval tools which leads to poor filing and slow retrieval; and limited sensitization of the library information resources and services as factors that hinder the effective utilization of library resources and services.

Mellon (2006) concluded in his study that undergraduates encounter technical problems trying to locate materials from university libraries. Beyond the problem of facilities is the inability of students to use different search strategies to source information and how to source the academic information needed for them to excel. Studies conducted among undergraduate students have shown that most of them are inexperienced in using libraries. Kamanda (1999) for instance conducted a study at the East African School of Library and information Science Library, Makerere University, Uganda. He observed that more than half the students experience problems in locating library information materials. He noted that the majority either located materials through browsing the library collections on the open shelves or sought assistance from library staff, but they did not make full use of the card catalogue. Hartmann (200I) concluded in his study that undergraduate students experienced difficulty in locating items from the library collection and do not understand the processes for retrieving journal articles.

This study therefore emanates from the above findings. Undergraduate students' information seeking behaviour was considered the biggest problem to be investigated. To do so, we set ourselves the following research questions:

- What are the reasons undergraduate students in the humanities search for information?

- What are the sources of information they use in obtaining information in the humanities?

- What are the different information searching strategies employed by the students in the humanities?

\section{Literature review}

\subsection{Theoretical frameworks on information seeking and searching}

Models of information seeking attempt to describe the process a user follows to satisfy an information need. The present study anchors on the David Ellis information seeking model. Ellis (1989) identified six actions: starting, chaining, browsing, differentiating, monitoring, and extracting. According to Ellis (1989), starting is identifying the initial materials to search through and selecting starting points for the search. Starting, as its name implies, is usually undertaken at the beginning of the information seeking process to learn about a new field. Starting could also include locating key people in the field or obtaining a literature review of the field. It is also common to rely on personal contacts for informal starting information.

Ellis (1989) explained chaining as following leads from the starting source to referential connections to other sources that contribute new sources of information. Common chaining techniques are following references from a particular article obtained by recommendation or a literature search to references in other articles. It's also quite natural to pursue the works of a particular author when following these chains. There are two kinds of chaining (Ellis 1989):

I.Backward chaining: is following a pointer or reference from the initial source. For example, going to an article mentioned in the initial source's bibliography.

2.Forward chaining: is looking for new sources that refer to the initial source e.g. using a citation index to find other sources that reference the initial source.

Ellis (1989) explained browsing as casually looking for information in areas of interest. This activity is made easy by the nature of documents to have tables of contents, lists of titles, topic headings, and names of persons or organisations. Browsing is being open to serendipitous findings; finding new information; and learning, which can cause information needs to change.

Differentiating, one of the search strategies as explained by Ellis (1989) is selecting among the known sources by noting the distinctions of characteristics and value of the information. This activity could be ranking and organizing sources by topic, perspective, or level of detail. Differentiating is heavily dependent on the individual's previous or initial experiences with the source or by recommendations from colleagues or reviews. Monitoring is keeping up-to-date on a topic by regularly following specific sources. Using a small set of care sources including key personal contacts and publications, 
developments can be tracked for a particular topic (Ellis, 1989). Extracting is methodically analyzing sources to identify materials of interest (Ellis, 1989). This systematic re-evaluation of sources is used to build a historical survey or comprehensive reference on a topic.

2.2 Kuhlthau's model of the information searching process

Kuhlthau provides an additional model which focuses on the information search process from the user's perspective. Her six stages in the Information Searching Process (ISP) Model are:

I.Initiation - beginning the process, characterized by feelings of uncertainty and more general ideas with a need to recognize or connect new to existing knowledge.

2.Selection - choosing the initial general topic with general feelings of optimism by using selection to identify the most useful areas of inquiry.

3.Exploration - investigating to extend personal understanding and reduce the feelings of uncertainty and confusion about the topic and the process.

4.Formulation - focusing the process with the information encountered accompanied by feelings of increased confidence.

5. Collection - interacting smoothly with the information system with feelings of confidence as the topic is defined and extended by selecting and reviewing information.

6.Presentation completing the process with a feeling of confidence or failure depending on how useful the findings are (Kuhlhau, 1994).

Applying Ellis' Model to information seeking involves actions such as starting (using lectures and to some extent reading lists, colleagues and the card catalogue); browsing (especially on the open shelves); chaining (using references at the back of consulted books); monitoring (using the card catalogues, lists on library notice boards, and colleagues); extracting (using the card catalogue) and differentiating (to differentiate between the many documents identified by a user and select what is appropriate for use to satisfy an identified need). In the Ellis model, users may move from one action to another and no order is assumed.

2.3 Undergraduate students' information needs

Kakai, Ikoja-Odongo and Kigongo-Bukenya (2004), in their findings on the reasons for undergraduates searching for information revealed that the main information needs that led undergraduate students into searching for information include: course works and assignments ( 86 percent), preparation for examinations and tests (68 percent), general reading to enhance lecture notes (55 percent), and class group discussions (44 percent). Seminars or preparation for workshops ( 10 percent), tutorial presentations ( 15 percent) of these had a lower rating. Ajiboye and Tella (2006) also concluded that the predominant information required by undergraduate students is academic information. Their study revealed that, academic information was rated the highest with 1282 (64.I percent) students, other information required by the students but which may not be as vital as academic information are: information for personal development with 250 ( 12.5 percent) students, health information with 225 ( 1 I.25 percent) student, employment information with 186 (9.3 percent) students and global information with 57 (2.85 percent) students.

Urquhart et al., (2006), in their study to know the reasons why undergraduate students use electronic resources concluded that undergraduate students in all three cycles answered that they were using electronic resources primarily for coursework, which could be background research, preparing for presentations, or making lecture notes, but the effect of modularization was apparent in the dominance of the use of electronic resources to help in preparing assignments.

2.4 Information sources used in obtaining information

Fidzani (1998) conducted a study in the University of Botswana, Gaborone, to establish the information needs and information seeking behaviour of undergraduate students. His findings revealed that there was a heavy reliance on library books, textbooks and Journals as sources of information used for course-work. The researcher further stated that students primarily relied on scanning the shelves, or browsing through journals than using the index and abstract databases to locate information. In agreement with Fidzani (1998)'s findings, Urquhart et al., (2006), also concluded in their study that despite the apparent predominance of the search engine and e-mail as part of sources of information behaviour, books are still considered a reliable, basic resources of information for students' academic work. Their study also showed that many students still turn to books as well as the Internet for routine academic queries, with books used first more frequently than the Internet. According to the researchers, often, both might be used to answer a query, with books used for orientation first, before doing an Internet search.

In like manner, Osiobe (1998) stated that browsing through Journals was the most important source of finding references for undergraduates students. He concluded that respondents in the University of Botswana did seek help from 
university library staff with 40 percent receiving help from the reference librarian and approximately 32 percent from the subject librarian. While Hillers (2002) in a study conducted in the University of Washington stated that undergraduates preferred to visit the library to study rather than to search for journals or books. Similarly Seiden, Szymborski and Bargara cited by Callinam (2004), conducted a research on a focus group with undergraduate students from Skidmpore College in New York and found that the students had a strong overall preference for digital resources. These preferences were explained to reinforce the lack of familiarity for printed sources such as books. Kerin, Madden, and Fulton (2004), in their study of undergraduate engineering students reported that the majority of the students indicated that the Internet was the first sources of information they used for a project, assignments. Mittermeyer (2003, also reported that many students used the Internet extensively for finding course-related information.

Lippincott and Kyrillidou (2004), in their study to reveal information seeking behaviour of undergraduate students found that 90 percent of students used search engines on a daily basis and 19 percent used the library daily as place of importance to the undergraduate students. OCLC (2002), on their white paper on the information seeking behaviour of students reported that 7 out of 10 students used the library's website for some assignments and also the most frequent uses were of full text Journals (67 percent), library catalogue ( 57 percent), and databases and indexes (5I percent). Majid and $\mathrm{Ai}$ (2002), studied the use of information resources by computer engineering students in Singapore and found that the top five information resources in order of preference were books ( 94 percent), lecturers ( 84 percent), the Internet (86 percent) and friends ( 84 percent). They relied heavily on printed sources of information and their use of electronic journals and databases was very low.

Kakai, Ikoja-Odongo and Kigongo-Bukenya (2004) in their study to establish what information institutions the students preferred using most and how much they valued them, students were asked to select and rank each information source. The findings revealed that lecture notes and handouts were the most preferred and used sources, followed by using departmental book-banks and then the university library. Consulting and photocopying from colleagues took the fourth position, followed by using Internet sources, while the university bookshop took the last position. The researchers contends that, considering the nature and range of information resources in each of the sources used, the university library was noted the only well-established institutional information source with varied information resources for further investigation.

Ajiboye and Tella (2006), in their study on information seeking behavior of undergraduate students in the University of Botswana revealed that Internet is the most consulted source by the students. This was confirmed by the overwhelming majority of the participants 1089 (54.4 percent) using the Internet. Next to it is the students lecture notes and handouts with 312 ( 15.6 percent). The library was rated as the third source of information that is most consulted by the students. Other sources indicated are: Textbooks 97 (4.3 percent); Newspaper 79 (4 percent); Electronic resources 68 (3.4 percent); consulting colleagues 50 (2.5 percent); CD - ROM Database 42 (2.I percent) and printed Journals 20 (I percent).

\subsection{Information searching strategies used by undergraduate students}

Buchanan, Cunningham, Blandford and Rimmer (2006), conducted a research on information seeking behaviour of undergraduate students in the humanities and observed that a few basic strategies had a common central role in the digital library use of these users. Chaining i.e. (using references at the back of consulted books) was one key strategy that formed the basic approach to finding contemporary academic research literature. The researchers also showed that, the undergraduate students in the humanities using the academic community as a source of recommendations demonstrated their academic reliance on human resources, particularly when established in their field. They also found that using a mixture of these two approaches formed the common foundations on which their information searching strategies were based.

Kakai, Ikoja-Odongo and Kigongo-Bukenya (2004) in their study to determine the search strategies undergraduate students uses in the process of their search for information concluded that, browsing collections and chaining both indicated a high significance level which shows that browsing collections and chaining were among the undergraduate students' information search strategies. On students' starting techniques Kakai, Ikoja-Odongo and Kigongo-Bukenya (2004) provided options such as using recommended reading list; searching through the subject catalogue; inquiring directly from lecturers; inquiring from colleagues; searching directly on the shelves; searching through e-resources; searching through the journal contents to identify relevant articles, and browsing the Internet. According to the researchers, using lecturers was the only statistically significant starting option used by undergraduate students, whereas searching directly on the shelves, e-resources, journal contents and browsing the Internet were significantly not used by the students as starting point. 
Seiden, Szymborski and Norelli (1997), in their study of information seeking strategies of undergraduate students noted that students preferred to limit information seeking to digital and full text resources because of time pressures and convenience, and that student did seek help from librarians, thus creating opportunities for education about not only the system, but information seeking strategies in general. Thompson (2003), in his study on information seeking behaviuor of undergraduate students noted that they preferred to start research with search engines and students preferred to seek help from peers or from faculty and not consult library staff or seek assistance from library web sites. Similarly, VanScoyoc and Cason (2006), in their study to examine undergraduate students' information seeking behaviour at the University of Georgia also found that students used search engines and web portals at 76 percent of the time and class websites was used almost as frequently at $7 \mathrm{I}$ percent of the time. The study also revealed that library OPAC and licensed databases was used at 36 percent of the time.

Bartley (2006), in his study of information searching activities of MIT (Massachusetts Institute of Technology) students, provided participants with instructions, asking them to document their information searching tasks for the period of one week by taking photos or screen shots and notes on what they did, and also with interview carried out with them revealed that browsing collections was one valued means mentioned by students in the discovering of research materials. According to the scholar, participants physically browsed library collections nine times during the study week, and this strategy was mentioned as important by the participants. The study also revealed that, of all the tasks performed by the participants (undergraduates), only 32 percent of the methods used revealed that student relied on web-based tools such as Google, Google print, Amazon and Wikipedia for many of their information needs and 39 percent of all tasks in the study involved the use of one or more of these web-based tools (Bartley, 2006).

Whitmire (2003), in his study on information seeking behaviour and epistemological beliefs of undergraduate students (seniors) at Yale University established that epistemological beliefs appear to correlate with information searching activities. According to the researcher, most common information searching activities was citation chaining, browsing stocks, browsing journals. He also observed that students had problems with topical searches, and that help and advice were commonly sought from faculty, graduate students and peers (Whitmire, 2003).

\section{Methodology}

The study is a descriptive survey and covers 100-400 level undergraduate students in history in the humanities in three universities in the South-South geo-political zone of Nigeria. They are Niger Delta University Amassoma, Bayelsa state, Delta State University Abraka, Delta State and University of Port-Harcourt, Rivers State. The population of this study is 867 being the total population of all 100-400 level undergraduate students in the department of history 2007/2008 session from the three universities. The sample size of 259 was generated being $30 \%$ of the total population of 867 used for the study.

The sampling procedure adopted in this study is cluster sampling technique, where the researchers arrived at cluster units made up of level of study, gender, and institution. Having identified the appropriate clusters, the researchers composed a list of all sample units and a simple random sampling of each cluster was selected from the list of sampled. Questionnaire was used for the data collection for the study. The questionnaire was entitled "Information Seeking Behaviour of Undergraduate Students in the Humanities Questionnaire (ISBUSHQ)". The questionnaire is made up of 30 items covering the various research questions raised to guide the study. The split-half method of testing reliability was employed in testing the reliability co-efficient of the instrument using another separate institution different from the ones used for the study. The value of 0.78 was obtained as the reliability co-efficient of the instrument, using the Pearson's product-moment formula.

To supplement the data from the questionnaire, the researchers engaged some of the students in history department of the three universities on a visit to the various institutions in a structured oral interview in which the students' responses were recorded down. Observation method was also used to know the undergraduate students information seeking patterns, and the strategies they use in searching for information in the various university libraries. Out of the 259 questionnaires administered to the respondents in their various classrooms, 250 completed questionnaires were returned and were used for the analysis. Data collected was analyzed using frequency counts and percentages.

\section{Results and discussions}

4.1 Demographic information on the respondents

The analysis of data regarding the biographical characteristics of the respondents shows that out of the 250 respondents, I I 2 (44.8 percent) indicated as male students, while 138 (55.2 percent) indicated as female students that participated in the survey. Out of the 250 respondents, 8I (32.4 percent) are from Niger Delta University, 92 (36.8 percent) are from University of Port-Harcourt, and 77 (30.8 percent) are from Delta State University all from the history department in the 
humanities. Analysis on the level of study showed that 76 (30.4 percent) of the respondents indicated as 100 level students; 56 (22.4 percent) indicated as 200 level; 63 (25.2 percent) indicated as 300 level; and 55 (22.0 percent) indicated as 400 level.

\subsection{Reasons undergraduate students search for information}

The study revealed that the information needs that make the undergraduate students search for information is academic information with the highest rating 233 (93.2 percent), followed by personal information with 10 (4.0 percent), and sports information with least rating 7 (2.8 percent). The responses revealed that the undergraduate students need academic information to write their course assignment, seminar papers, prepare for their class discussions, and prepare for their examinations and tests, and information to write their final year research papers more than any other information such as personal and sports information. The strong need for academic information was supported by a student interviewed when she said, "I need information write my assignments, prepare my presentations, seminars, and write my final year project" (Undergraduate student-400Level- Niger Delta University). This finding is in conformity with Kakai, Ikoja-Odongo and Kigongo-Bukenya (2004)'s findings when they said often students' information seeking behavior involves active or purposeful information as a result of the need to complete course assignment, papers, and write their final year research work. The findings of this study revealed that students have information needs that relate to their studies.

\subsection{Information sources used by students}

To establish the sources the undergraduate students used in the humanities, they were asked statements to either agree or disagree. The findings revealed that 206 (82.4 percent) of the respondents indicated using the library as source of information to obtain information to meet their information needs; 177 (70.8 percent) indicated using archival materials as sources of information to obtain information for their academic work; and I73 (69.2 percent) indicated using chiefs/ community heads as sources of information. Others are: 172 (68.8 percent) indicated using journal articles as sources of information; 164 (65.6 percent) indicated using the Internet as source of information they used in obtaining information; and 139 ( 55.6 percent) indicated using databases as sources of information they used in obtaining information. Other sources indicated by the students are lecturers, colleagues, lecture notes, reference materials as sources of information they used in obtaining information to meet their information needs. The result revealed that the undergraduate students in the humanities used sources such as the library, archival materials, journal articles, Internet, databases, chiefs / community heads, lecturers, colleagues, reference materials to obtain information to meet their academic information needs. The study revealed heavy reliance on library books and Journals, also on human resources such as community heads/chiefs, lecturers and colleagues for information to meet their information needs.

These findings are in agreement with Fidzani (1998)'s findings when he reported that there was a heavy reliance on library books and Journals. Interview with a student from Niger Delta University (NDU) also confirmed this idea when he said "I used sources like published and unpublished works, subject experts, oral tradition, Internet, archival materials" (Undergraduate student - 400 level, Niger Delta University). Buchanan et al, (2006) also support this finding when they stated that, the undergraduate students in the humanities demonstrate their academic reliance on human resources.

\subsection{Information seeking behaviour students compared to David Ellis model}

To determine the information search strategies used by the undergraduate students in line with Ellis six search strategies, they were asked statements to either agree or disagree. The result revealed the following: 139 (55.6 percent) of the respondents indicated that they used lecturers and colleagues as starting point to obtain academic information; 137 (54.8 percent) of the respondents indicated using references at the back of consulted books (chaining) as a search strategy to source for relevant materials; and 163 (65.2 percent) of the respondents indicated that they browse the library collections to retrieve relevant information materials. Others are: 150 (60.0 percent) indicated using differentiating strategy (selecting among the known sources by noting the distinctions of characteristics and value of the information); 143 (57.2 percent) indicated using monitoring (using the card catalogues, lists on library notice boards); and I 26 (50.4 percent) indicated using extracting strategy i.e. using the library card catalogue as a search strategy to retrieve relevant materials. The study revealed that undergraduate students used the following search strategies when seeking information: starting (using lecturers or colleagues), browsing library collections on the shelves, chaining (using references at the end of books), differentiating, monitoring and extracting (using the card catalogue).

These findings are in agreement with David Ellis information seeking model which focuses on the behaviour of information seeking activities. An interview with an undergraduate male student in the History Department revealed the use of search strategies such as "starting". "I started by getting from a textbook ... because it's quick, easy, gives me some basic information often to start with. It might help me too, if I meant some research or something on the internet getting into a 
book first gives me some ideas, keywords to put in them. I will probably go to the Internet and have a look at research articles probably after that ..."(Undergraduate student-300 level, Delta State University).

The use of other search strategies like browsing the library collections was one search strategy common to the undergraduate students of Niger Delta University, Delta State University, and University of Port-Harcourt. This was revealed in an interview with a female student in history department. "I have not used the card catalogue; I go straight to the shelf to retrieve the book I want because we know where the books are on the shelf" (undergraduate student - 400level, University of Port-Harcourt). The researchers observed that some students because of their inability to use the card catalogue to extract relevant materials, they end up by going straight to browse the collections on the shelves. This was confirmed in an interview with a student. "When I started, I took a long time to find out what was there (card catalogue). I just go direct, not using the library catalogue, straight to the textbooks on the shelves" (undergraduate student- 400 level Delta State University). The reveals that the students avoid using the library catalogue to retrieve information materials probably due to their inability to use the catalogue. This finding is in agreement with Agyen-Gyasi (2008) finding in an interview with undergraduate students at Kwame Nkrumah University of Science and Technology (KNUST) that they have problems using the catalogue, locating books on the shelves, and going through borrowing procedures.

\section{Conclusion}

Information gathering could be a challenge and an arduous task to the tertiary institution students in Nigeria. These students are loaded with many assignments and class presentations which required them to source for information on their own. As revealed from this study, the predominant information needed by undergraduate students is academic information to enable them write their assignments, seminar papers, prepare for their class discussions, examinations and tests, and to write their final year research papers more than any other information such as information on personal life, social life, health information, employment, and global information which were all rated low by the undergraduate students. Understanding the actual needs of information users and taking steps to satisfy them is the first step towards effective service provision. Librarians, especially those involved in bibliographic instructions should be interested in ways undergraduate students approach the library and the methods they use to search for needed information to meet their academic information needs. Librarians could redesign strategies intended to improve the provision of library services especially towards information skills development and information resource awareness.

The university libraries face a number of challenges in its user's instruction programs, yet it is through user education that the librarians' work is made easy and the students' efforts quickened while retrieving and utilizing the library's information resources. In this respect, the current library user institution programs in Niger Delta University, Amassoma, Bayelsa State, Delta State University, Abraka, Delta State and University of Port-Harcourt, River State, should be enhanced to empower students with the benefit of using information resources in all formats, and be proficient in library use.

\section{Recommendations}

Students in tertiary institutions need information for their academic activities and this can not be taken for granted. To minimize most of the problems mentioned above, the following recommendations are made:

- Library administrators should collaborate with faculty to work towards making university authorities to see the reason to integrate the course 'information literacy' into the school curriculum.

- Sensitization should be used as the main tool to ensure that the students are well equipped and informed of the information resources and services in the university libraries. To ensure appropriate sensitization, the university libraries should actually use a variety of marketing tools, including using notice boards in faculties and halls of residence, guides, and instruction booklets to ensure that users are always informed of what to do when in the library. University libraries should use attractive posters in each section of the library describing the services and scope of collections.

- A well articulated and sustained effort is required to provide Information and Communication Technology (ICT) facilities (Internet) in Nigerian university libraries and make the same more accessible to the students by providing computers with Internet connectivity in the universities libraries in Nigeria.

- The user instruction workshops should be marketed using flyers and pamphlets, promoting the collections, services and library regulations in general and provide current editions of video coverage that includes new developments in the library to be used to introduce fresh students to the library and its services.

- Students should also properly be initiated and guided by librarians and faculty into being good information resource users so that they do not depend mainly on lecture notes to accomplish their knowledge goals by collaborating with faculty to integrate information literacy course into the school curricula.

- The library management should lobby for funds to enable them purchase current textbooks and subscribe to current journals both local and international journals in all area of study.

SA JnI Libs \& Info Sci 2010, 76(2) 


\section{Acknowledgements}

The authors wish to thank $\operatorname{Dr}$ S. O. Uwaifo for his thorough guidance, encouragement, and inspiration during the research, as well as the anonymous reviewers and the editor for valuable suggestions.

\section{References}

Agyen-Gyasi, K. 2008. User education at the Kwame Nkrumah University of Science and Technology (KNUST) Library: prospects and challenges. Library Philosophy and Practice. [Online]. http://www.accessmylibrary.com/archive/74322-libraryphilosophy-and-practice/june-2008.html. (Accessed 20 July 2009).

Ajiboye, JO and Tella, A. 2006. University undergraduate students' information seeking behavior: implications for quality in higher education in Africa. [Online]. http://www.tojet.net/article/6/4.doc. (Accessed 20 June 2009).

Baro, EE and Fyneman, B. 2009. Information literacy among undergraduate students in Niger Delta University. The Electronic Library, 27 (4): 659-675.

Bartley, M. 2006. User needs assessment of information seeking activities of MIT (Massachusetts Institution of Technology) students - Spring 2006. [Online]. http://macfadden.mit.edu/webgroup/userneeds-report.pdf. (Accessed July 10, 2009).

Buchanan, G., Cunningham, S]., Blandford, and Rimmer, J. 2006. Information seeking by humanities scholars. [Online]. http:// www.ucl.ac.uk/slais/claire-warwick/articles/ECDL2.doc. (Accessed I0 July 2009)

Ellis, D. 1989. A behavioral model for information retrieval system design. Journal of Information Science, 15 (4): $237-247$.

Enochsson, A. 2005. A gender perspective on Internet use: consequences for information seeking. Information Research, 10(4). [Online]. http://informationr.net/ir/l0-4/paper237.html. (Accessed 23 January 20I0).

Fidzani, BT. 1998. Information needs and seeking behaviour of graduate students at the University of Botswana. Library Review, 47(7): 329-340.

Hartmann, E. 200I. Understanding of information literacy: the perception of first year undergraduate students at the University of Ballarat. Australian Academic and Research Libraries, 32 (2): 35-43.

Hillers, S. 2002. How different are they? A comparison by academic area of library use, priorities and information needs at the University of Washington, Issues in Science and Technology Librarianship. [Online]. http://www.ist.org/02-winter/article.html. (Accessed 10 January 2010).

Kakai, M., Ikoja-Odongo, R and Kigongo-Bukenya, IMN. 2004. A study of the information seeking behavior of undergraduate students of Makerere University, Uganda. World Libraries, 14 (I): 14-26.

Kamanda, RW. 1999. Library-use by university students: case study of the East African School of Library and Information Science. Kampala: Makerere University.

Kerin, G., Madden, R and Fulton, C. 2004. Information seeking and the students studying for professional careers: the case of engineering and law students in Ireland. Information Research, I0(I): 208-220.

Kuhlhau, CC. 1994. Seeking meaning: a process approach to library and information services. Nowood, N.J.: Abex.

Lippincott, S and Kyrillidou, M. 2004. How ARL University community access information: highlights from LibQUAL. ARL Bimonthly Report 236. [Online]. http://www.arl.org/news/tr/236/lqaccess.html. (Accessed I0 July 2009).

Majid, S and Ai, TT. 2002. Usage of information resources by computer engineering students: a case study of Nanyang Technology University, Singapore. Online Information Review, 26(5: 318-328.

Mann, T. 2003. Library research models: a guide to classification, cataloguing and computers. New York: Oxford University Press.

Mellon, CA. 2006. Library anxiety: a grounded theory and its development. [Online]. http://www.library.arizona.edu/users/ buchwaln/undergraduate.html. (Accessed I0 June 2008).

Mittermeyer, D. 2003. Information literacy: study of incoming first year undergraduates in Quebec. Paper presented at the conference of Rectors and principals of Quebec, Universities, Montreal. [Online]. http://www.creuq.ca/documents/bibl/formation/ studies_Ang.pdf. (Accessed 10 July 2010).

OCLC, 2002. OCLC White paper on the information seeking behaviour of college students: How academic librarians can influence student's web - based information choice. [Online]. http://www.oclc.org/research. (23 January 2010).

Osiobe, SA. 1998. Information seeking behaviour. International Library Review, 20 (3): 337-346.

Seiden, P., Szymborski, K and Norlli, B. 1997. Undergraduate students in the digital library: information seeking behaviour in an heterogeneous environment. ACRL $8^{\text {TH }}$ National Conference, April, Nashville, TN. [Online]. http://www.ala.org/ala/acrlbucket/ nashville 1997pap/seidenszymborski.htm. (2 July 2009).

Steinerova, J and Susol, J. 2007. Users' information behaviour- a gender perspective. Information Research, 12(3), 12-35.

Taylor, R. 2000. Undergraduates' use of periodicals: implication for libraries reference work. Reference Librarian, 27(4): 5I-65.

Thompson, C. 2003. Information illiteracy or lazy: how college students use the web for research. Portal, 3 (2): 259-268.

Tibbo, HR. 2002. Primary history: historians and the search for primary source materials. Proceedings of the $2^{\text {nd }} A C M / I E E E-C S$ Joint Conference on Digital Libraries. [Online]. ieeexplore.ieee.org/iel5/8569/27/27/0 I 204845.pdf. (Accessed I0 January 20 I0).

Urquhart, C., Lonsdale, R., Thomas, R., Spink, S., Yeoman, A and Armstrong, C. 2006. Uptake and use of electronic information services: trends in UK higher education from the JUSTEIS Project. Library and Information Science Research, 25 (I): $95-100$.

Van-Scoyoc, AM and Cason, C. 2006. The electronic academic library: undergraduate research behaviour in a library without books. Portal, 6 (I): 47-58.

Watson - Boone, R. 2004. The information needs and behaviour of humanities scholars. RQ, 8(2): 203-216.

Whitmire, E. 2002. Discipline differences and undergraduates' information seeking behavior. Journal of the American Society for information Science and Technology, 53 (8): 63I-638.

Whitmire, E. 2003. Epistemological beliefs and the information seeking behavior of undergraduates. Library and Information Science Research, 25: 127-142. 
Wiberley, SE. and Jones, WG. 2000. Patterns of information seeking in the humanities. College and Research Libraries, 50 (6): 638-645.

Zondi, EL. 2002. Library use skills and information seeking patterns of first year students at the University of Zululand, SouthAfrica. South- African Journal of Library and information Science, 60 (4): 204-208. 